\title{
Community Capacity Strengthening for Covid-19 Disaster Prevention through the Independent Quarantine Installation
}

\author{
Eko Teguh Paripurno1,2, Elmi Wibowo², Panji Dwi Ashrianto' and Gandar \\ Mahojwala $^{1,2}$
}

${ }^{1}$ University of Pembangunan Nasional Veteran Yogyakarta

2KAPPALA Indonesia Foundation

e-mail: paripurno@upnyk.c.id

Article History

accepted 31/08/2020

approved 22/09/2020

published $28 / 10 / 2020$

\begin{abstract}
In Timbulharjo Village, Sewon District, Bantul Regency, Special Region of Yogyakarta, the Covid-19 pandemic has reached its fifth month. Individual citizens have economic limitations in preventing a pandemic. Refusal of migrants / refugees who need a place of independent isolation has the potential to increase conflict. These conditions make the installation of independent isolation and the accompanying empowerment program needed by community. This program helps solve citizens' problems. The program was built through collaborative community service and facilitation processes, thereby stimulating residents to realize other local initiatives in dealing with Covid-19. This dedication not only provides relief items, but also harmonizes local planning, management and resources that can be carried out independently by the community. Planning and implementation of the program is done on a multi-party basis (pentahelix). Citizens as subjects supported by the village government, educational institutions, business institutions, and the media. University of Pembangunan Nasipnal Veteran Yogyakarta represent educational institutions, in which there are Disaster Management Study Program, Disaster Management Study Centers, Covid-19 Task Force, UPN TV, and Alumni Association.
\end{abstract}

Keywords: CBDRM, Prevention, Covid-19, Independent Isolation

\begin{abstract}
Abstrak
Di Desa Timbulharjo, Kecamatan Sewon, Kabupaten Bantul, Daerah Istimewa Yogyakarta, pandemi Covid-19 sudah sampai bulan ke lima. Warga secara individu mempunyai keterbatasan ekonomi dalam mencegah pandemi. Penolakan pendatang / pengungsi yang memerlukan tempat isolasi mandiri berpotensi meningkatkan konflik. Kondisi tersebut menjadikan instalasi isolasi mandiri serta program pemberdayaan yang menyertainya diperlukan komunitas. Program ini membantu menyelesaikan masalah warga. Program dibangun melalui proses-proses fasilitasi dan pengabdian masyarakat kolaboratif, sehingga merangsang warga dalam mewujudkan inisiasi-inisiasi lokal lainnya dalam menghadapi Covid19. Pengabdian ini tidak hanya memberikan barang-barang bantuan, namun juga menyelaraskan perencanaan, pengelolaan dan sumberdaya lokal yang secara utuh dapat dilaksanakan oleh masyarakat secara mandiri. Perencanaan dan pelaksanaan program dilakukan secara multi-pihak (pentahelix). Warga sebagai subyek yang didukung oleh pemerintah desa, lembaga pendidikan, lembaga usaha, dan media. UPN "Veteran Yogyakarta mewakili lembaga pendidikan, yang didalamnya ada Magister Manajemen Bencana, Pusat Studi Manajemen Bencana, Gugus Tugas Covid-19, Teve UPN, dan Ikatan Alumni.
\end{abstract}

Kata kunci: PRBBK, Pencegahan, Covid-19, Isolasi Mandiri

Social, Humanities, and Education Studies (SHEs): Conference Series https://jurnal.uns.ac.id/shes

p-ISSN 2620-9284

e-ISSN 2620-9292 


\section{PENDAHULUAN}

Berdasarkan data EM-DAT, ada sekitar 464 bencana besar yang terjadi di Indonesia antara tahun 1900 dan 2016 yang menewaskan lebih dari 240.000 orang, menempatkan negara ini di peringkat atas. Kondisi kerentanan Indonesia ini semakin diperparah dengan mewabahnya Corona virus Disease (Covid-19) di Indonesia. Covid19 menjadi ancaman besar dan terus berlanjut di seluruh daerah di Indonesia.

Penelitian ini muncul berdasarkan adanya kebutuhan untuk memetakan model pengurangan risiko bencana berbasis komunitas untuk ancaman Covid-19 dengan mengarusutamakan pengelolaan modal sosial masyarakat lokal. Terutama setelah kebijakan pemerintah untuk pasien positif Covid-19 dengan gejala ringan dan sedang tidak lagi dilayani rumah sakit. Saat ini, rumah sakit secara efektif hanya dapat mengurusi pasien dengan kondisi kritis. Latar belakang inilah yang menyebabkan masyarakat harus berinisiasi untuk menyediakan fasilitas isolasi mandiri yang memenuhi kebutuhan komunitasnya dan tentu inisiasi-inisiasi penunjang lainnya. Sehingga pada penelitian ini, penulis menitikberatkan pada pemodelan implementasi modal sosial untuk manajemen pengurangan risiko Covid-19, secara khusus melihat praktek yang telah dilakukan di Dusun Tembi. Dusun ini merupakan bagian dari Desa Timbulharjo, Kecamatan Sewon, Kabupaten Bantul, yang merupakan salah satu desa wisata yang mashyur. Dusun ini juga terdampak gempabumi Yogyakarta pada tahun 2006. Situasi ini yang memperkaya respon masyarakat di Tembi, dengan adanya kolaborasi multi aktor dari masyarakat, badan usaha, dan organisasi non-pemerintah.

Sejak Maret telah ada inisiasi dari Dusun Tembi dalam upaya pengurangan risiko Covid-19, yaitu membangun kesadaran kritis dan kolektif warga, mewujudkan relawan, pendataan mobilisasi warga, meningkatkan peran organisasi lokal, kajian risiko, perencanaan pengurangan risiko Covid-19, membangun fasilitas isolasi mandiri komunitas, dan meningkatkan kualitas sosial-ekonomi warga. Berbagai upaya yang dilakukan komunitas ini menggunakan modal sosial yang ada di Dusun. Inisiasi ini timpang dengan kondisi di komunitas lain di Indonesia yang belum siap untuk merespon Covid-19 di tingkat kewenangannya. Pemberitaan di media telah menunjukkan kondisi ini, termasuk di Magelang, Pati, dan Jombang .

Kondisi ini menggambarkan urgensi pemodelan tingkat komunitas yang dapat direplikasi ke daerah-daerah lain. Peneliti berargumen, pemodelan ini tidak hanya berguna dalam penerapan ke Dusun lain, namun bahkan ke tingkat Desa. Replikasi ini diharapkan dapat mempermudah daerah lain dalam mencapai inisiasi pengurangan risiko dan mencapai ketangguhan komunitas dalam menghadapi ancaman Covid-19. Tentu, model ini tidak hanya mencakup aktivitas luaran dalam merespon Covid-19, namun juga membangun gerakan dan kesadaran warga agar percaya diri, mampu, dan berkomitmen dalam melakukan aktivitas pengurangan risiko bencana.

Begitu juga pasca adanya kewenangan pemerintahan desa untuk membuat peraturan desa melalui Undang-Undang No. 6 Tahun 2014 tentang Desa. Peraturan desa ini dapat digunakan untuk mewadahi aturan-aturan lokal yang awalnya tidak tertulis yang sudah ada di masyarakat. Hal ini yang menjadi bagian dari penelitian ini, yaitu mengkaji peran regulasi tingkat desa dalam pengurangan risiko bencana Covid19 di Dusun Tembi.

Pendekatan pengurangan risiko bencana berbasis komunitas (PRBBK) dipilih oleh peneliti dikarenakan selama ini, pendekatan dalam pengurangan risiko bencana adalah dengan pendekatan fisik dan infrastruktur, yang top-down dan jarang memberikan hasil keberlanjutan dalam pengurangan risiko bencana. Pengetahuan lokal pun kerap diabaikan dalam pendekatan infrastruktur tersebut. Sedangkan, PRBBK dapat memikat aktor yang lebih inklusif dan pengetahuan yang beragam. Dengan PRBBK, komunitas rentan dan komunitas adat yang termarjinalkan memiliki peran. Jika menelesuri penelitian terdahulu yang dilakukan pada Dusun Tembi, tidak 
ada yang terkait dengan bencana. Pada tingkat Desa Timbulharjo, sangat sedikit pula penelitian yang terkait dengan bencana.

Dari latar belakang yang telah dipaparkan di atas dapat dirumuskan masalah penelitian sebagai berikut: (1) Bagaimana implementasi modal sosial untuk pengurangan risiko Covid-19 di Dusun Tembi? (2) Bagaimana pengurangan risiko Covid-19 Dusun Tembi dibandingkan dengan Protokol Normal Baru Desa dalam Keputusan Menteri Desa, Pembangunan Daerah Tertingga, dan Transmigrasi Nomor 63 Tahun 2020? (3) Bagaimana model implementasi modal sosial untuk ancaman Covid-19 untuk pengurangan risiko Covid-19 di Dusun Tembi?

Penelitian ini bertujuan untuk: (1) Mengkaji implementasi modal sosial untuk pengurangan risiko Covid-19 di Dusun Tembi. (2) Mengkaji perbandingan pengurangan risiko Covid-19 Dusun Tembi dibandingkan dengan Protokol Normal Baru Desa dalam Keputusan Menteri Desa, Pembangunan Daerah Tertingga, dan Transmigrasi Nomor 63 Tahun 2020. (3) Mengkaji model implementasi modal sosial untuk ancaman Covid-19 untuk pengurangan risiko Covid-19 di Dusun Tembi.

\section{METODE}

Penelitian ini merupakan penelitian kualitatif dengan menggunakan alat-alat Participatory Rural Appraisal (PRA). Metodologi kualitatif merupakan prosedur penelitian yang menghasilkan data deskriptif berupa kata-kata lisan, tertulis, dan perilaku yang diamati. Inti dari penelitian kualitatif adalah memahami melalui kerangka referensi mereka sendiri.

PRA adalah sekumpulan pendekatan dan metode yang berfungsi dalam mempelajari tentang kehidupan dan kondisi pedesaan oleh, bersama, dan dari masyarakat desa. PRA merefleksikan metode partisipatoris, yang bertujuan mengubah realitas sosial berdasarkan pengetahuan yang dalam ke praktik sehari- PRA juga dapat digunakan untuk memungkinkan masyarakat desa dalam berbagi, meningkatkan, dan menganalisa ilmu kehidupan dan kondisi yang mereka miliki, untuk berencana dan bertindak. berikut:

Metode pengumpulan data yang digunakan dalam penelitian ini adalah sebagai

1. Observasi. Dalam teknik observasi, peneliti menggunakan teknik observasi partisipatif, observasi terus terang, dan observasi tersamar sesuai dengan keadaan.

2. Wawancara. Dalam teknik wawancara, peneliti menggunakan wawancara semiterstruktur. Jenis wawancara semi terstrutur sudah termasuk dalam kategori wawancara mendalam, di mana dalam pelaksanaannya lebih bebas bila dibandingkan dengan menemukan permasalahan secara lebih terbuka, di mana pihak yang diajak wawancara diminta pendapat dan ide-idenya. Wawancara ini juga akandikembangkan menjadi diskusi grup terfokus, karena diskusi grup terfokus pada dasarnya adalah bentuk wawancara mendalam yang dilakukan dalam

3. Studi dokumen. Dalam studi dokumen, peneliti akan melakukan studi pada dokumen sejarah, ceritera, peraturan, dan kebijakan baik yang dalam bentuk lisan maupun tulisan yang mendukung penelitian ini. Hal ini dikarenakan studi dokumen merupakan pelengkap dari penggunaan metode observasi dan wawancara.

Dalam penelitian ini, sampel sumber data diambil secara purposive. Purposive sampling adalah teknik pengambilan sampel sumber data dengan pertimbangan tertentu, baik paling tahu tentang apa yang diharapkan peneliti, maupun memiliki. Informan kunci yang dipilih adalah tokoh dusun, anggota organisasi, dan gugus tugas Covid-19 Dusun Tembi. 
Teknik analisis data dalam penelitian ini menggunakan teknik analisis data model interaksi menurut Miles \& Huberman, yang mengemukakan bahwa aktifitas dalam analisis data kualitatif dilakukan secara interaktif dan berlangsung terus- menerus hingga tuntas sampai data tersebut jenuh. Aktivitas dalam analisis data, yaitu data reduction, data display, dan conclusion drawing / verification.

\section{HASIL DAN PEMBAHASAN}

Penyiapan tempat karantina mempunayi dua tujuan utama antara lain: (1) Sebagai tempat karantina warga Tembi yang mudik dari luar kota. (2) Sebagai tempat karantina warga Tembi yang terinfeksi covid 19. (3) Tempat karantina yang disiapkan berada di Kesekretariatan Kappala Indonesia yang berada di Dusun Tembi. (4) Pemenuhan Fasilitas dasar tempat karantina.Diskusi tentang kesepakatan prsyarat fungsi rumah karantina dan isolasi mandiri ditampilkan pada tabel 1.

Tabel 1. Kesepakatan prasyarat fungsi rumah karantina dan isolasi

\begin{tabular}{|c|c|c|c|}
\hline NO & PARAMETER & KARANTINA & ISOLASI \\
\hline 1 & APD & $\begin{array}{l}\text { Masker, mantel pelindung, } \\
\text { sarung tangan (handscoen), } \\
\text { pelindung muka, sepatu } \\
\text { boot }\end{array}$ & $\begin{array}{l}\text { Masker, mantel pelindung, } \\
\text { sarung tangan } \\
\text { (handscoen), pelindung } \\
\text { muka, sepatu boot }\end{array}$ \\
\hline 2 & Tempat tidur & Bersama berjarak @ 9 m3 & Terpisah@9m3 \\
\hline 3 & Sirkulasi udara & Baik, langsung ke luar & Baik, langsung ke luar \\
\hline 4 & Cuci tangan & $\begin{array}{l}\text { Bersama/terpisah, sabun, } \\
\text { tisu kering, tempat sampah, } \\
\text { air mengalir }\end{array}$ & $\begin{array}{l}\text { Terpisah, sabun, tisu } \\
\text { kering, tempat sampah } \\
\text { tertutup, air mengalir }\end{array}$ \\
\hline 5 & MCK & $\begin{array}{l}\text { Bersama//terpisah. } \\
\text { Desinfektan sebelum dan } \\
\text { sesudah dipakai. } \\
\text { Perlengkapan mandi } \\
\text { terpisah. Akses mudah, } \\
\text { jumlah memadai }\end{array}$ & $\begin{array}{l}\text { Terpisah / bersama. } \\
\text { Desinfektan sebelum dan } \\
\text { sesudah dipakai. } \\
\text { Perlengkapan mandi } \\
\text { terpisah, akses mudah }\end{array}$ \\
\hline 6 & Cuci pakaian & $\begin{array}{l}\text { Bersama//terpisah, } \\
\text { direndam sabun }\end{array}$ & Terpisah, direndam sabun \\
\hline 7 & Lokasi & $\begin{array}{l}\text { Rumah bersama, bukan } \\
\text { pemukiman padat }\end{array}$ & $\begin{array}{l}\text { Rumah terpisah, bukan } \\
\text { pemukikan padat }\end{array}$ \\
\hline 8 & Konsumsi & $\begin{array}{l}\text { Bersama, oleh keluarga / } \\
\text { warga }\end{array}$ & $\begin{array}{l}\text { Terpisah, oleh keluarga / } \\
\text { warga }\end{array}$ \\
\hline
\end{tabular}


$9 \quad$ Alat makan \& masak

10 Drainase

11 Sampak

12 Ruang terbuka

13 Hiburan

14 Transportasi

15 Keamanan

$16 \quad$ Aksesibilitas

$17 \quad$ Komunikasi

18 Penerangan
Terpisah, oleh keluarga / warga

Sistem tertutup, resapan

Tempat tertutup, dibuang terpisah

Tersedia, berjarak $>2$ meter

Terpisah / bersama jaga jarak, Memadai, dapat diakses mandiri

Tersedia mobil, sopir dan 1 pembantu

24/7, mandiri, koordinasi dengan gugus tugas setempat

Di ruang, tidur, MCK, dapur, halaman, dan ruang lain secara terbatas, dengan memfasilitasi disabilitas fisik dan sensorik mandiri

Bebas melakukan komunikasi tidak langsung. Dapat melakukan komunikasi langsung. Tidak melakukan kontak. Jaga jarak

Memadai, dapat diakses mandiri
Terpisah, oleh keluarga / warga

Sistem tertutup, resapan

Tempat tertutup, dibuang terpisah

Tersedia, berjarak $>2$ meter

Terpisah, Memadai, dapat diakses mandiri

Tersedia mobil, sopir dan 3 pembantu

24/7 koordinasi dengan gugus tugas setempat

Di ruang, tidur, MCK, dapur, halaman, dan ruang lain secara terbatas, dengan memfasilitasi disabilitas fisik dan sensorik.

Bebas melakukan

komunikasi tidak langsung. Hindari komunikasi lengsung

Memadai, dapat diakses mandiri

Karantina untuk warga yang mudik dari luar kota juga dilakukan karantina mandiri oleh keluarga dari warga yang pulang kampung. Dari bulan Maret sampai bulan Agustus 2020 kurang lebih ada 9 warga Tembi yang menjalani karantina mandiri. Kesepakatan kebutuhan barang untuk menjamin proses karantina berjalan baik, maka disepakati kelengkapan-kelengkapan seperti tercantum pada tabel 2. 
Tabel 2. Kesepakatan kebutuan perlengapan rumah karantina dan isolasi

\begin{tabular}{|c|c|c|c|}
\hline NO & BARANG & JUMLAH & UNIT \\
\hline 1 & Tempat tidur & 3 & set \\
\hline 2 & Meja besar & 2 & buah \\
\hline 3 & Meja kecil & 3 & buah \\
\hline 4 & Kursi panjang & 2 & buah \\
\hline 5 & Kipas angin & 3 & buah \\
\hline 6 & Dispenser & 1 & buah \\
\hline 7 & Kotak tissue & 3 & buah \\
\hline 8 & Tempat sampah & 3 & buah \\
\hline 9 & APD & 5 & stel \\
\hline 10 & Kaos tangan & 1 & kotak \\
\hline 11 & Desinfektan kecil & 3 & paket \\
\hline 12 & Masker kain & 30 & buah \\
\hline 13 & Alat mandi & 3 & paket \\
\hline 14 & Ember cuci & 3 & buah \\
\hline 15 & Sabun cuci & 3 & paket \\
\hline 16 & Kompor gas & 1 & buah \\
\hline 17 & Tabung gas & 1 & buah \\
\hline 18 & Magic com & 1 & buah \\
\hline 19 & Wajan & 1 & buah \\
\hline 20 & Panci & 1 & buah \\
\hline 21 & Ceret & 1 & buah \\
\hline 22 & Piring & 1 & lusin \\
\hline 23 & Gelas & 1 & lusin \\
\hline 24 & Sendok & 1 & lusin \\
\hline 13 & Alat mandi & 3 & paket \\
\hline 14 & Ember cuci & 3 & buah \\
\hline 15 & Sabun cuci & 3 & paket \\
\hline 16 & Kompor gas & 1 & buah \\
\hline 17 & Tabung gas & 1 & buah \\
\hline
\end{tabular}

Barang-barang tersebut di atas diadakan karena kontribusi banyak pihak. Masyarakat Tembi merupakan motor dari kegiatan ini. Selanjutnya kegiatan ini didukung oleh berbagai pihak, berupa unsur-unsur dapam pentahelix. Kappala Indonesia merupakan unsur masyarakat dan lembaga masawadaya masyarakat. UPN "Veteran" Yogyakarta merupakan unsur akademisi, yang kebetulan mempunyai program penguatan masyarakat untuk pencegahan dan penanganan Covid-19. Hotel Yabbikayu, D'omah Hotel dan Leksa Ganesha Batik Gallery merupakan unsur lembaga usaha lokal. Unsur media sebagai kontributor diseminasi hasil. Lembaga usaha lain yang terlibat adalah kelompok penjahit dan kelompok peternak ikan lele. 


\section{SIMPULAN}

Inisiasi masyarakat dengan sedikit keterlibatan dari desa menjadi pelajaran tersendiri dari Desa Timbulharjo. Masyarakat bersama jejaring sosialnya membangun kerjasama bersama dengan pelaku di luar desa. Kerjasama dengan berbagai pelaku dalam skema penta helix menyebabkan efektifitas kerja dan keragaman pilihan respon yang dapat dilakukan oleh masyarakat. Dengan demikian, pilihan respon di Tembi, Desa Timbulharjo lebih beraneka ragam. Sasaran masing-masing respon lebih spesifik sehingga seluruh komponen masyarakat seperti perempuan, anak, dan keluarga rentan lebih terlindungi oleh respon yang direncanakan. Karena pengalaman gempa yang terjadi sejak lama. Keterlibatan aktor di luar desa membantu tidak adanya pengkajian risiko dan dokumentasi strategi sehingga peran yang dimainkan masyarakat dapat terdistribusi dengan baik.

Makalah ini menyimpulkan bahwa ada cukup praktik yang menunjukkan bahwa mempraktikkan Destana dengan PRBBK dapat berhasil mengurangi risiko di tingkat desa dan masyarakat. Namun, tugas selanjutnya adalah mendorong respons dari bencana umum terhadap Covid-19 serta membuat desa lain meniru praktik Desa Pondokagung dan Timbulharjo untuk menjamin keselamatan masyarakat di tingkat desa dan masyarakat. Praktik dari kedua desa tersebut membuktikan bahwa setiap masyarakat memiliki banyak pilihan yang dapat dilakukan dengan memanfaatkan sumber daya lokalnya untuk mengurangi risiko Covid-19.

Suatu kehormatan bagi penulis untuk mengucapkan terima kasih kepada seluruh dosen di Program Studi Magister Manajemen Bencana - Jirisan Teknik Lingkungan Fakultas Teknologi Mineral Universitas Pembangunan Nasional 'Veteran' Yogyakarta.

\section{DAFTAR PUSTAKA}

BNPB. (2012). Peraturan Kepala BNPB No. 1 tahun 2012 tentang Desa / Kelurahan Tangguh Bencana. Jakarta: BNPB.

Lassa., et.al. (2018) Twenty Years of Community-Based Disaster Risk Reduction Experience from a Dryland Village in Indonesia. Journal of Disaster Risk Studies. Vol 10 No 1.

Paripurno, E.T., Ninil, M.J. (ed.). (2014). Panduan Pengelolaan Risiko Bencana Berbasis Komunitas. MPBI.

Undang-undang No. 24 of 2007 tentang Penanggulangan Bencana

Paripurno, E.T., et.al. (2015). Efektifitas Sistem Peringatan Dini Berbasis Masyarakat Pada Erupsi Gunungapi Kelud 2014. Proceeding of FPTPRB National Conference.

Andreastuti, S., et.al. (2019). Character of Community Response to Volcanic Crises at Sinabung and Kelud Volcanoes. Journal of Volcanology and Geothermal Research, Vol. 382.

Murakami, H., Pramitasari, D., Ohno, R. (2008). Human Casualty and Damage Distribution in Relation to Seismic Intensity in the 2006 Central Java Earthquake in Indonesia. The $14^{\text {th }}$ World Conference on Earthquake Engineering, China.

BNPB. (2017). Standar Nasional Indonesia No. 8357: 2017 tentang Desa / Kelurahan Tangguh Bencana. Jakarta: BNPB.

BNPB. (2020). Modul 5: Rencana Kontingensi, Modul Pelatihan Desa dan Kelurahan Tangguh Bencana untuk Fasilitator. Jakarta: BNPB. 